\title{
"Lacerman" Comic Character Design With Morphological Forced Connection Method (Mfc)
}

\author{
Muhammad Iskandar ${ }^{1}$, Sonson Nurusholih ${ }^{21,2}$ Visual Communication Design Department \\ Creative Industry Faculty - Telkom University \\ E-mail: ${ }^{1}$ clickstu75@gmail.com, ${ }^{2}$ sonson@telkomuniversity.ac.id
}

\begin{abstract}
Character figures are vital elements in a narrative story, especially with the presence of the characters in the story. Without the presence of characters with strong characterizations, a story in a comic will not be interesting to be read. This research will focus on how to design a comic character using the morphological forced connection transformation method. The final result of the research is a form of comic characters with a combined form of humans and animals where the process of making these characters can be a foothold for illustrators who want to make a character of a kind. This research method uses a qualitative descriptive method, with data collection methods carried out through a variety of literature studies, as well as tracing documentation data. The Matrix Manga Theory from Hiroyoshi Tsukamoto was used to give personality figures, the fundamental theory of Human Drawing from Andrew Loomis as a foothold to make anatomy. The final results of the study will be (1) New characters combined figures of humans and animals (2) drawing method to create characters using the morphological forced connection method.
\end{abstract}

Keywords : Comic Characters, morphological forced connection

\section{INTRODUCTION}

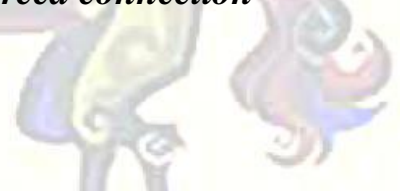

In a comic story, the presence of characters gives decorating a plot as one of the important elements. Most comic stories revolve around the struggle of good against evil. The figure that appears as a figure of kindness is usually a human against an evil character. Some comic characters are portrayed as human beings who have a two-sided nature where in daily life a good character is shown, but in the action this character turns into a hero or an evil character. There is also a comic character that was originally just a human, when something happens, for example, when eradicating or fighting a crime, then it turns into a creature that resembles to an animal.

One comic character that uses an animal as its main object is Lizards. Lizard is a fictional character published by Marvel Comics in an American comic book story. He tells that the character of Lizards is described as an enemy of the figure of a superhero character, Spider-Man. 


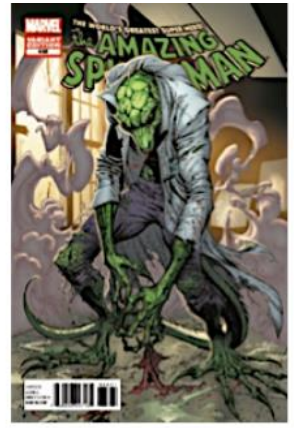

Figure 1

Lizard

Source: https://www.marvel.com/comics/

Stan Lee and Steve Ditko are the creators of this antagonist reptile-shaped and first it appeared in the comic series entitled The Amazing Spider-Man \# 1. This comic was published in November 1963 and then this character also presented in the film The Amazing Spider -Man, whose film had been circulating in 2012. In the story, it is said that this Lizard is actually someone named Curt Connors who is told as a talented surgeon and was assigned to the United States army. Curt Connors is obsessed with reptiles especially lizards because the nature of these animals is able to grow its tail even though the tail is broken. Narrated Curt Connors Curt found a serum that can make humans to able to regenerate their own bodies. But at that time, because Curt did not have humans to be used as experimental objects, the serum was injected into Curt's body. Then at first, the serum acted positively, even Curt's right hand grew as it was. But slowly, Curt's behavior began to change due to the serum and then his body instead turned into a fierce giant lizard.

From the description of the Lizard character excerpt above, it can be concluded that there is a transformation of the shape of humans with a combination of animals that form creatures to be a new character and it can be adopted in a comic story. Portrayals of animal characters in combination with human figures have been made by many world-famous illustrators in various forms. Like Wolverine which is described as having claws like a mink, Hawkman who has wings, Aquaman is told to breathe in water and his body scaly like a water animal and live in the depths of the sea.

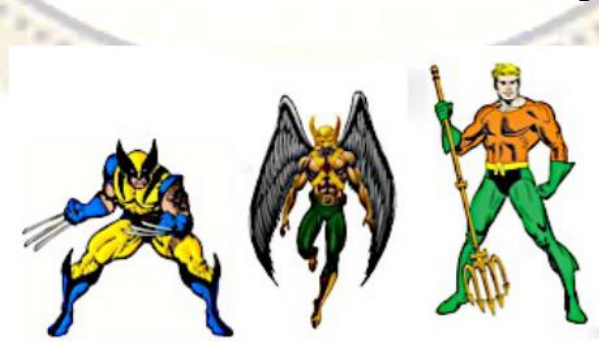

Figure 2

Comic Characters : Wolverine, Hackman dan Aquaman source : google.com

In the picture of the comic characters above, we can see a human figure who has an animal element in his body but it does not leave his true form as a human. The 
combined depiction of humans and animals above tends to be easier because in its adaptation, animal elements are only as a complement to the character's abilities. But what if the characters that will be made are a combination of both (human and animal), then there will be many problems encountered such as body anatomy, the unification of animal and human body parts and of course the proportional and the form that will appear will be strange in plain sight.

\section{RESEARCH METHOD}

This research is a qualitative research with the final result in the form of comic character design through a visual illustration approach. The design process is made through observation by collecting a variety of data and information in the form of images, documents, and writings / articles and journals that support this research. For the supporting theory of character design using the Manga Matrix theory approach from Hiroyoshi Tsukamoto in his book "Manga Matrix", for depicting the anatomy of characters used the fundamental theory of Andrew Loomis's Human Drawing, as well as for the method of merging the elements of the body of character objects using the morphologycal forced connection method. As for the application of theory to the design of illustrations of comic characters as follows:

\begin{tabular}{|l|l|}
\hline Theory & Application \\
\hline $\begin{array}{l}\text { Manga Theory } \\
\text { Hiroyoshi } \\
\text { Tsukamoto's matrix }\end{array}$ & $\begin{array}{l}\text { Designing } \\
\text { characters and } \\
\text { personality } \\
\text { comic } \\
\text { characters }\end{array}$ \\
\hline $\begin{array}{l}\text { Fundamental theory } \\
\text { Human Drawing } \\
\text { Andrew Loomis }\end{array}$ & $\begin{array}{l}\text { Basic depiction } \\
\text { of the anatomy } \\
\text { of the body of } \\
\text { the character to } \\
\text { be made }\end{array}$ \\
\hline $\begin{array}{l}\text { Character design } \\
\text { method }\end{array}$ & $\begin{array}{l}\text { Merging } \\
\text { elements of the } \\
\text { Morfologycal Forced } \\
\text { honnection Model } \\
\text { with animal } \\
\text { objects }\end{array}$ \\
\hline
\end{tabular}

Tabel 1 : Theory Chart and Its Application Source: Author Decumentation

The following description of the theory used in the design of comic character characters: 


\subsection{Matrix Manga Theory}

In summary, matrix manga theory is a method in which the idea is initially a character which is then divided in details of each of its elements to create a new character. There are three variable stages in designing a character, namely:

1. Form Matrix is a method of the matrix by determining the parameters of the form as a reference. This shape matrix uses a variety of objects combined to be a new object. For example, a flying horse character or known as Pegasus is a combination of horse and bird. The manga-matrix diagram model matrix form is described as follows:

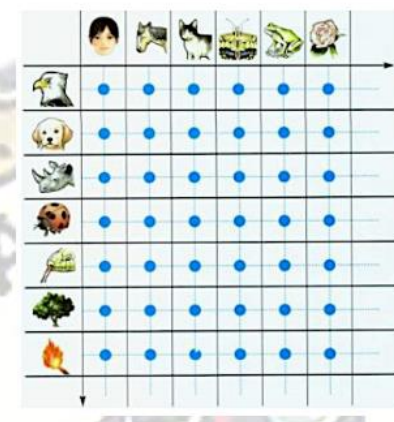

Figure 3

Hiroyoshi Tsukamoto's Manga Matrix Diagram

Source: Author Decumentation

2. Costume Matrix which is a parameter in developing costumes that fit the theme of the character object to be created. As for the development of this costume not only as a body protector, in developing a costume, but also the design created will be a feature and be a reflection of a character's character. Example: the costume used by Batman reflects the personality of the character.

3. Personality Matrix, namely the use of elements that exists in each character as an amplifier of various personalities attached to the characters created. As for parsing any personality matrix inherent in a character design the hexagon personality approach is used which includes: specific attributes, weaknesses / deficiencies, status / profession, environmental origin, desires, and behavior.

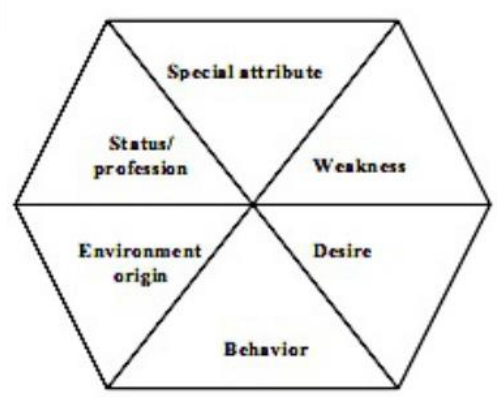

Figure 4

Hexagon Characteristic Diagram

Source: Author Decumentation 


\subsection{Fundamental Theory of Human Drawing Andrew Loomis}

The shape of the body that exists in humans is a synergistic combination of bones with muscles, flesh, as well as the functions of organs, and skin that completely covers it. This organic system is entirely a very dynamic and interconnected system. Human body shape from time to time with age, will change form from birth, baby, childhood, adulthood to old age tent as a form of evolution related to biological processes that will be experienced by anyone. With every change of form a mirror of each person's personality appears. There are some people who have a gentle types of character, some are hard and rough, others are humorous, some are cunning type, and so forth.

Before designing a character, a creator is required to master the basics of drawing such as the perception of the object image, both sense perception, character capture, and mastery of drawing techniques. In the book "Fundamental Human Drawing" by Andrew Loomis some things that become the main key in the formation of pictures of the human body namely:

a. Anatomy: is a form or figure of body posture in humans whether it is a man or a woman which includes muscles and other parts.

b. Posture is the posture of the human body with a variety of heights in short. Body posture can be said to be ideal if the body blooms with full muscle.

c. Limbs are important parts of the human body including several important body parts from top to bottom, namely the head, body, hands and feet.

d. Muscle is a network of elements forming body posture that moves bones in the body.

e. Mimic is a character that is on a human face, generally formed because it is from innate birth or the atmosphere that shapes it.

f. Figure is a figure that exists in human appearance with a variety of social characters, both in behavior and social role.

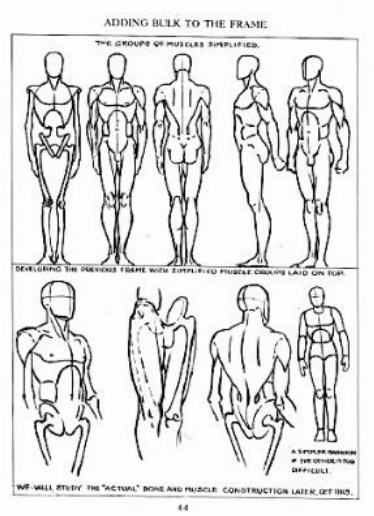

Figure 5

Human Drawing

Source: Author Documentation 
The method used in the design of these lizard human characters uses qualitative method as stated by Sugiyono (2011, P.15), research with qualitative method tends to use descriptive analysis. What is highlighted in this qualitative research is the process and meaning (subject perspective). In addition, the theoretical basis used is as a guide so that the focus of the research results will be in accordance with the facts in the field. Furthermore, this theoretical foundation can also be useful to provide an overview of the research setting as well as material for similar research.

In terms of designing a design, which aims to create a comic character for example, the design method is defined as a systematic and planned work sequence in solving problems encountered through alternative selection. With this method, it is possible to conduct a rational analysis in determining realistic initial conditions.

Another method used in designing comic characters is the morphological forced connection method. In general, the morphological forced connection method can be interpreted as a method of automatically integrating parameters into a new combination as a stage of problem solving. Each product or design consists of several parts, or can be broken down into several components. Each component, if separated, has its own characteristics, materials, forms, but it cannot work if it is not combined with other components. Thought that the design results consist of components, so if some or all components are changed, it will produce a new design. One method of morphological forced connection that is often used for a character design is based on the Manga Matrix book by Hiroyoshi Tsukamoto (2006, p.14-15) matrix method used to create characters using mathematical methods. By breaking an object into parts and then arrange the position and function column into a matrix diagram ( $\mathrm{X}-\mathrm{Y}$ axis).

\section{RESULTS AND DISCUSSION}

The process of designing comic characters is done in several stages. The first stage is to provide the personality or personality of this character with a characterization matrix with hexagon chart model Hiroyoshi Tsukamoto. The personality of the character "Lacerman" is described as follows:

Special attributes; in this human lizard design, the person behind this lizard man has an alter ego which in Latin is interpreted as "the other me" is a vertebrate zoology lecturer who likes to study vertebrate reptile animals.

1) Weakness; Like a lizard, in a state of urgency the lizard will release its limbs in deceiving danger, while Laceman will become a human lizard when pressed against an evil person.

2) Status or profession; Characters that will be made are named Lacerman, Lacer comes from Laceritilia, another name for vertebrate animals, in other words Laceman is a vertebrate (lizard) man, Lacerman will be described as a figure of kindness who fights against various acts of evil. 
3) Original environment; Lacerman is said to come from the neighborhood area of the big city

4) Desire: human nature and animal nature that rely on instincts make this character have a desire to be able to protect and survive

5) Behavior; This character can turn into a human lizard at any time, especially when carrying out their duties as a crime repellent.

The next step is to conduct an anatomical study of the character's planned plans, namely human anatomy and lizards. Furthermore, the results of human and animal anatomy studies are to release parts or elements of each organ of the human body and lizards by using a matrix of shapes with tables with columns containing parts of the human and animal bodies.
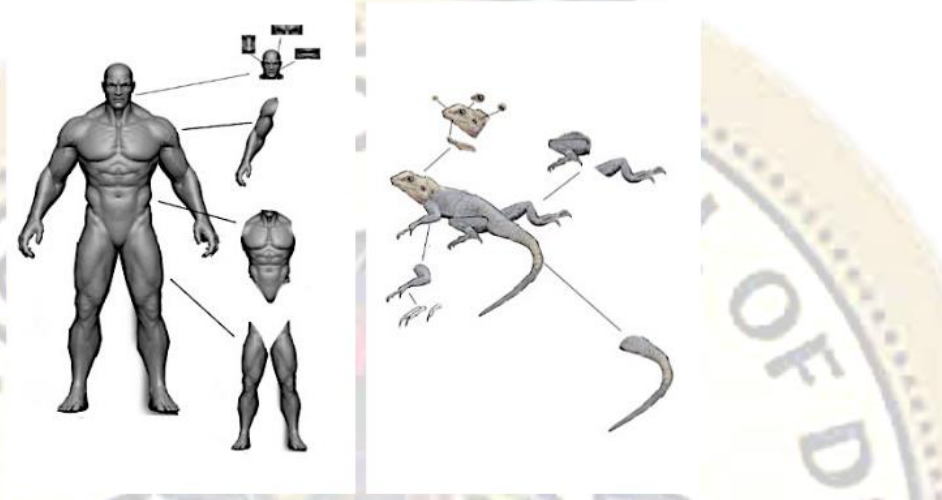

Figure 6

Animal anatomy (lizard) studies Source: Author Documentation

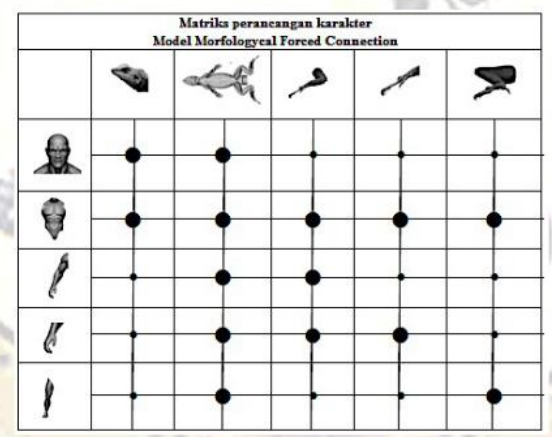

Figure 7

Morphological Forced Connection Matrix

Source: Author Documentation

From the above table, the next process is to determine which elements of the human anatomy and lizards are combined to form a new body by applying the Morphological Forced Connection method with the following results: 


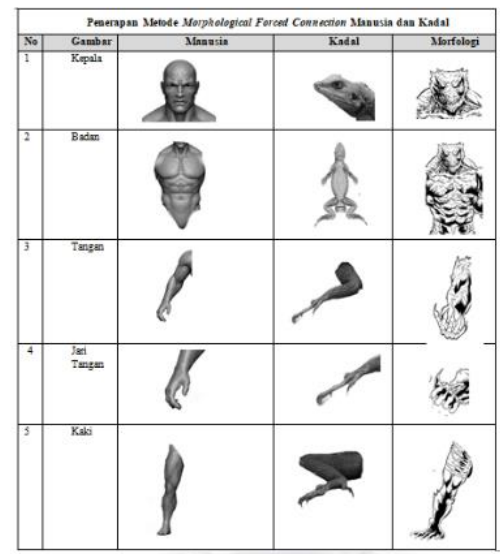

Figure 8

Matrix Combination with Morphological Forced Connection Method

Source: Author Documentation

The final step is to refine the anatomy of new characters with the fundamental theory of Human Drawing from Andrew Loomis with the following results:
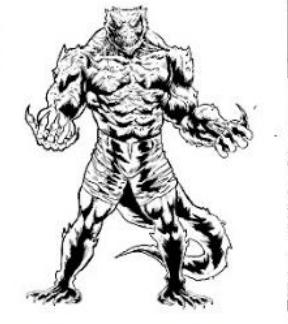

I

Figure 9

The character of the comic character Lacerman

Source: Author Decumentation

\section{CONCLUSION}

In the process of making a character for a comic story there are several steps that can be done to produce a good design methodically. For the creator who wants to make a character, the steps that the author has taken can be an example of the process for designing similar characters.

The process of making a human character with animals can be started by making plans or concepts to be made. The first step is to make observations, what character characters will be made. For the theoretical approach, we can use the theory of characterization or characterization matrices (personality matrix). The strength of a character will be judged by the extent to which the use of theory and design methods is in accordance with the theory. 
Next is the knowledge and understanding of the development of the anatomical shape of the body with the fundamental human drawing theory approach as the basis for making the anatomical shape of the character's body. And finally, for the incorporation of elements of the human body and animals can use the method of morphological forced connection to get the desired end result.

\section{SUGGESTIONS}

The character "Lacerman" made by the writer is far from being perfect, but the efforts of the writer who made this character methodically on the basis of a theory that has often been used to believe the writer that a work such as making these characters can produce good work. For creators, especially comic artists, the use of the morphological forced connection method can be a reference for making similar characters of course with different design concepts and designs. Considering that Indonesia is rich with a variety of stories, legends and myths that can be appointed as a design of character designs that characterize Indonesian folklore.

\section{BIBLIOGRAPHY}

1) Loomis, Andrew. 2010. Figure Drawing for All It's Worth (How to draw and paint). Diunduh dari

https://issuu.com/kyliegirl/docs/figure_drawing_for_all_its_worth__andrew_loomis

2) Masdiono, Toni. 14 Jurus Membuat Komik. Jakarta: Creativ Media. 1998.

3) McCloud, Scott. Understanding Comics.Jakarta: Gramedia. 2001.

4) Sugiyono. 2011. Metode Penelitian Kuantitatif, Kualitatif dan R\&D. Bandung: Afabeta.

5) Tsukamoto, Hiroyoshi.. Manga Matrix: Create Unique Characters Using the Japanese Matrix System, USA: Collins Design. 2006

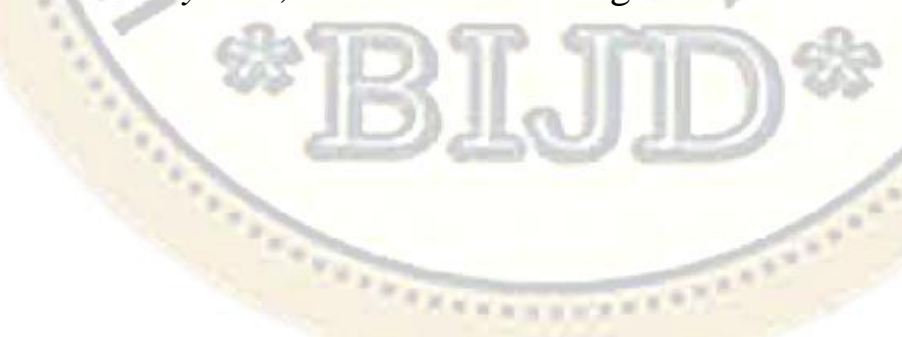


